\title{
Section 18C, Human Rights, and Media Reform: An Institutional Analysis of the 2011-13 Australian Free Speech Debate
}

\section{Chris Berg and Sinclair Davidson ${ }^{1}$}

\section{Abstract}

The paper examines two Australian freedom-of-speech controversies between 2011 and 2013 - the debate over section 18C of the Racial Discrimination Act, and the debate over the Gillard Government's print media laws. These controversies featured rhetorical and ideological debate about the limits of free speech and the nature of human rights. The paper applies a 'subjective political economy' framework to these debates in order to trace the effect of increased perceived 'disorder costs' and 'dictatorship costs' of freedomof-speech restrictions. The paper concludes that policy change is driven by exogenous changes in perceived institutional costs. In the case of the Gillard Government's media laws, those costs were borne by the Gillard Government, and one would not expect print media laws to be a major political issue in the absence of a further exogenous shock. In the case of section $18 \mathrm{C}$ the revealed dictatorship costs of legislation, which includes the words 'offend' and 'insult', suggest the section $18 \mathrm{C}$ controversy will endure.

\footnotetext{
1 The Institute of Public Affairs, chrisberg@gmail.com; RMIT University and the Institute of Public Affairs. The authors would like to thank two anonymous referees and the editor for their comments, and Simon Breheny and Morgan Begg for their invaluable help with this paper.
} 


\section{Introduction}

Between 2011 and 2013 Australia was engaged in a sustained debate about freedom of speech. This paper provides an institutional economic analysis of the key public policy issues in that debate. The first issue concerned restrictions on 'hate speech'. This debate was sparked by a 2011 court case, Eatock $v$ Bolt ('the Bolt case') and also a subsequent debate about a proposed Commonwealth Human Rights and Anti-Discrimination Bill (the 'HRAD Bill') in 2012. The second issue concerned regulatory control of the print media, beginning with the Gillard Government's Independent Inquiry into Media and Media Regulation (the 'Finkelstein inquiry') in 2011 that led to a legislative package of media controls introduced to parliament in 2013.

We employ a 'subjective political economy framework' (see Allen and Berg 2016) to examine these issues. Building on the insights of Djankov et al. (2003), in this framework institutional (or political) change is driven by shifts in the perceived trade-off between disorder costs and dictatorship costs of social control. Economists have long looked for a way to integrate ideas into their explanations of political and economic change (McCloskey 2015; Rodrik 2014). The subjective political economy framework allows us to explain how exogenous shocks disrupt the status quo and lead to the possibility of institutional change. With this framework we can draw some conclusions about the future trajectory of the freedom-of-speech debate in Australia.

A number of scholars have examined these controversies separately. Gelber and McNamara (2013) and Hirst and Keeble (2012) have placed questions of race and racism at the centre of the public debate surrounding the Bolt case. Likewise, Stone (2015) questions the apparently myopic focus on the Bolt case by conservative and liberal commentators. Tate (2016) considers that the Bolt case brought out competing visions of freedom of speech in the liberal tradition. Lidberg and Hirst (2013) and Finkelstein and Tiffen (2014) respectively characterise the response to the Finkelstein inquiry as 'hyperactive' and 'extreme'. Pearson (2012) considers proposals for media regulation in the context of Australia's absent constitutional protection for the free press. By contrast, the HRAD Bill has received less attention. Gelber and McNamara (2013) mention the HRAD Bill in passing, and note that many critics of the government's legislation rhetorically connected the HRAD Bill to the Bolt case.

We add to this growing literature in two ways.

First, we make good the existing literature's lack of the kind of clear politicaleconomy framework that will permit generalisable conclusions about how the debate proceeded. At the core of our framework we place the relative costs of 'disorder' and 'dictatorship', and the role of 'status quo disrupting' exogenous 
shocks producing pressure for institutional change. We advance two examples of this: first, where an exogenous shock has led to an increase in perceived dictatorship costs; and, second, where an exogenous shock has led to an increase in the perceived costs of disorder.

Second, we provide a close reading of the debate itself. While other scholars have purported to scrutinise the debate surrounding each of these episodes (Gelber and McNamara 2013; Stone 2015), the source material on which they found their analyses is thin, and that thinness leads to some critical mischaracterisations of the debate itself.

We conclude that exogenous shocks create the possibility of policy change, constrained by viable institutional alternatives to the status quo. In the case of the media reform process, the disorder costs were borne by the Gillard Government and with the expiry of that government we would not expect media reform to be a major political issue, at least in the absence of a further exogenous shock. In the case of s. 18C, however, we conclude that the revealed dictatorship costs of legislation that prohibits offensive or insulting language suggest the controversy will be ongoing.

\section{The subjective political economy approach and freedom of speech}

The subjective political economy approach is derived from the theory of comparative institutional economics developed by Djankov et al. (2003) and Shleifer (2005). Comparative institutional economics describes four broad general mechanisms to exert social control over organisations: 'market discipline, private litigation, public enforcement through regulation, and state ownership'. Each mechanism exists along an Institutional Possibility Frontier - a spectrum of institutional alternatives. The trade-off in distinguishing between these mechanisms is between disorder costs and dictatorship costs. Each social control mechanism imposes costs. As control moves towards dictatorship, social losses from public expropriation increase. As control moves towards disorder, social losses from private expropriation increase. Efficient institutions to impose social control over organisations minimise the sum of disorder costs and dictatorship costs. Consistent with Buchanan's (1975) insight that society exists 'between anarchy and leviathan', Shleifer (2005: 444) argues that the 'case for public intervention relies crucially on the presumptive failure of market discipline to control disorder'. 
In Figure 1 we adapt the Institutional Possibilities Frontier and apply it to the control of speech. Disorder costs now refer to the costs of uncontrolled speech. These possible costs include the effects of 'hate speech' (such as the communication of racism, homophobia or sexism), the effects of libel (damage to reputation), the effects of sedition (the damage to national security or social cohesion), the effects of low-quality speech (the harm of 'mindless' or 'low-brow' entertainment), and violations of privacy. Dictatorship costs include the loss of rights (such as the restriction on the human right to freedom of expression), democratic costs (the prevention of public discourse on public issues and the performance of government), and listener costs (restricting the suppressed speech from interested listeners). Absolute freedom of expression is shown on the top left of the Institutional Possibilities Frontier. The 'control' of speech under a such a regime is done through the market for ideas. State control, such as pre-publication censorship, criminal sanctions for speech, and direct state ownership of media outlets, is shown on the bottom right.

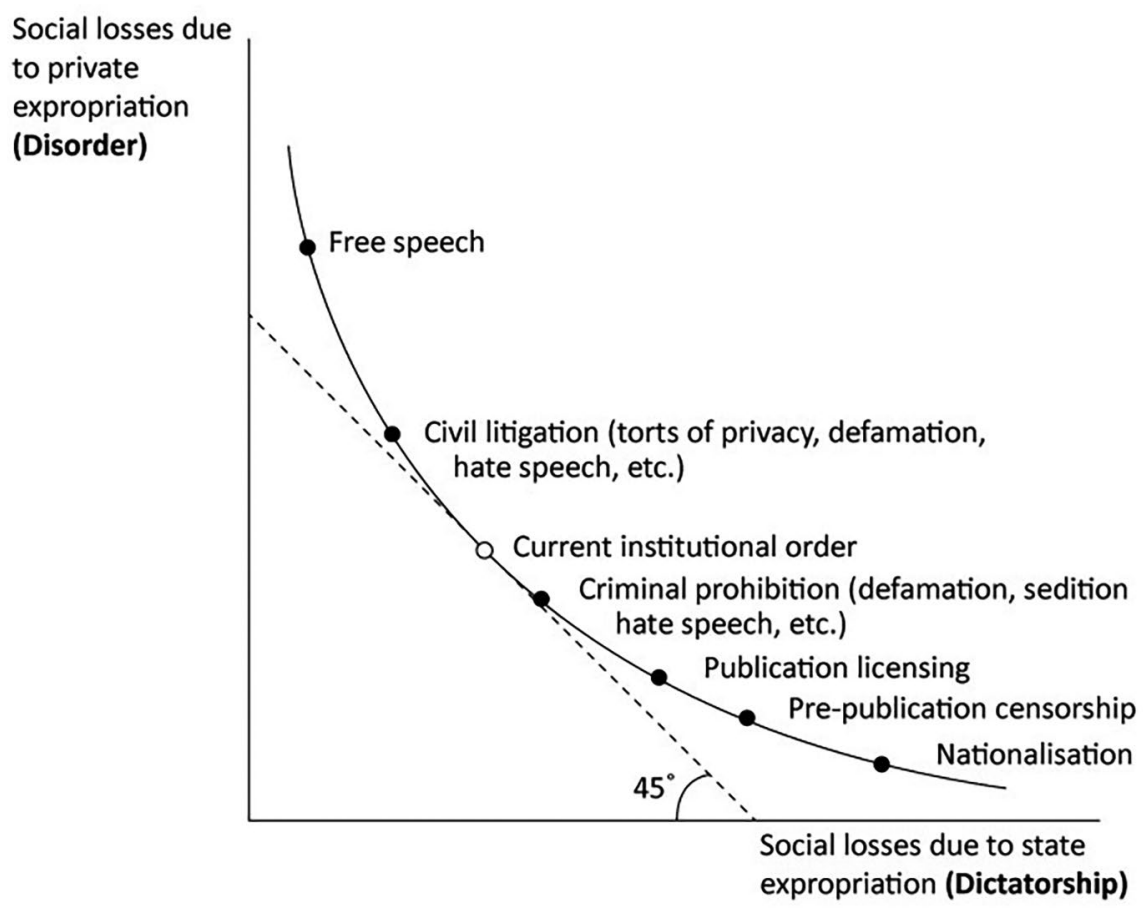

Figure 1: Optimising the social control of speech

Consistent with the Djankov et al. (2003) assumption that society has chosen the least costly institution of social control, the cost-minimising current institutional order is represented by the point of tangency between the 'isocost' (45 degree) line and the Institutional Possibilities Frontier. The curve is convex 
to the origin in order to represent that assumption. Figure 1 is indicative only. Australia's speech regime is for the most part a mixture of free speech and civil and criminal controls. Defamation is controlled by a mixture of the market of ideas, civil litigation and criminal defamation laws (Burgess 2013). Depending on jurisdiction, different forms of hate speech (such as discriminatory speech on racial or religious attributes) are controlled by civil litigation or left to the market of ideas. Recent anti-terror law changes have created a criminal offence of sedition in Commonwealth law (Lynch et al. 2015). Australia lacks a tort of privacy but serious or repeated violations of the Australian Privacy Principles can lead to a civil penalty order (Australian Law Reform Commission 2014). The 'quality' of speech is controlled through a combination of the marketplace and broadcasting codes of practice administered by the Australian Communications and Media Authority. High-brow speech is also directly provisioned by Australia's two state-owned broadcasters - the Australian Broadcasting Corporation and the Special Broadcasting Service.

As a framework to describe different institutional choices, the Institutional Possibilities Frontier has been criticised for being excessively vague, and for being unable to distinguish between different political systems (Rosser Jr and Rosser 2008). Allen and Berg (2016) build a framework of subjective political economy by modifying the Djankov et al. (2003) approach. First, they observe that while Djankov et al. assume that society has chosen the cost-minimising institution, dictatorship and disorder costs are subjective, rather than objective. Different agents will be more or less sensitive to dictatorship costs and disorder costs, depending on their ideological values and their personal or material interests. Individual agents will perceive restrictions on the right to speech differently. For example, it is well understood that the costs of hate speech are subjective. Likewise, the rights costs of controls on hate speech will be understood by different agents in different ways. Accordingly, agents will have different ideas about where on the Institutional Possibilities Frontier the most efficient institution lies - that is, where their Subjective Institutional Possibilities Frontier intersects with the cost-minimisation line.

Second, Allen and Berg (2016) disaggregate the Institutional Possibilities Frontier from a society-wide function to individual functions, observing that the institution that society chooses is the result of political bargaining between individuals and groups with subjective Institutional Possibilities Frontiers of different shapes. In this perspective, the 'current institutional order' as depicted in Figure 1 can also be described as the 'status quo'. Subjective Institutional Possibilities Frontiers shift over time in response to changes in perceived costs. Most agents will see the status quo as 'inefficient' in some way, representing the distance between the chosen institution and the cost-minimising point on the agent's subjective Institutional Possibilities Frontier. Changes in that perceived 
inefficiency offer an institutional theory of political salience. In Australia, policy change occurs through representative parliaments chosen by regular election. Perceived institutional inefficiencies lead to political change to the extent that agents have influence within the political system (Bueno de Mesquita et al. 2003) and have an incentive to seek that change (Olson 1965). Looking at the institutional control of free expression, this has some implications we will draw out in the conclusion. Subjective political economy allows the integration of changes in ideas into political economy analysis, and thus offers a useful way to describe the intertwined freedom-of-speech debates that were first sparked by the Bolt case in 2011 .

\section{Offensive speech: The Bolt case}

Section 18C of the Commonwealth Racial Discrimination Act 1975 provides a civil action for the control of hate speech. The section, introduced by the Racial Hatred Act 1995, makes it unlawful to 'offend, insult, humiliate or intimidate' a person or group on the basis of the 'race, colour or national or ethnic origin of that person or a member of the group'. The following section, s. 18D, provides a freedom-of-speech exemption for anything said or done 'reasonably and in good faith'.

While there had been substantial debate at the introduction of the Racial Hatred Bill (Costello 1994; Manne 1994; McGuinness 1994; Merkel 1994; Norton 1994; Rubenstein 1994, Ruehl 1997; Walsh 1995) - to the extent that opposition leader John Howard said he was willing to fight a double dissolution on its introduction (Willox 1995) - s. 18C had been more or less uncontroversial since it had been introduced (Meagher 2004; Rubenstein 2014). Prior to the Bolt case, the most substantial public attention given to an action under s. 18C concerned Holocaust denier Fredrick Töben (Debelle 2001), and s. 18C was widely perceived to be operating much as it had been expected to operate. Rubenstein (1994) described the aim of the legislation before its passage:

The law is directed at extremist fringe groups - the professional racists ... We are talking here about people who set out to convince others that certain ethnic groups deserve to be hated just because of who they are; that they should be discriminated against, harassed and even expelled or killed.

The law was advertised, and perceived, to operate so as to constrain high disorder costs associated with free speech. Rubenstein (1994) wrote that 'virtually nothing that currently appears in the mainstream media would be affected [by s. 18C]'. The Bolt case upset this institutional consensus, changing the perceived costs of s. $18 \mathrm{C}$ for some participants in the public debate. 
Eatock $v$ Bolt was an action brought about by Pat Eatock and others against The Herald Sun columnist Andrew Bolt and his employer The Herald and Weekly Times under s. 18C for a series of articles identifying light-skinned Aboriginal people 'who, out of their multi-stranded but largely European genealogy, decide to identify with the thinnest of all those strands, and the one that's contributed least to their looks' (Bolt 2009a, 2009b). In his judgment of 28 September 2011, Justice Bromberg found that the articles had breached s. 18C and did not qualify for the protections of s. 18D. The articles were neither 'fair comment' due to factual inaccuracies nor done 'reasonably and in good faith' because of the inflammatory language of the articles and their 'mocking and derisive tone'. The judgment provided for a corrective notice to be published in The Herald Sun and appended to the articles' online publication, and Bolt and The Herald and Weekly Times were prohibited from republishing the articles.

The Bolt case caused a storm of controversy. Conservative, classical liberal, and libertarian commentators called for either a substantial amendment or a complete repeal of s. $18 \mathrm{C}$ on the grounds that the Bolt case had revealed the dictatorship costs of s. 18C to be too high (Akerman 2014; Albrechtsen 2011; Allan 2011; Baume 2011; Berg 2010, 2014; Breheny 2014; Brown 2014; Cater 2014; Davidson 2011; Johns 2014; Kemp 2011; Kenny 2014; Merritt 2014; O'Neill 2014; Paterson 2011a; Roskam 2014; Sammut 2014; van Gend 2014; Wilson 2014; Windschuttle 2014). Likewise, a number of newspapers editorialised against s. 18C, including The Australian ('Smothering Free Exchange of Ideas a Dangerous Path, 2014), The Age ('Free speech has to include freedom to offend', 2012), The Herald Sun ('Your right to speak freely', 2014), and The Saturday Age ('Freedom of speech needs liberating', 2013).

In Figure 2 we show two subjective Institutional Possibility Frontiers depicting the positions of the agents involved in the debate.

Figure 2 shows the views of the critics of s. $18 \mathrm{C}$ as the blue pro s. $18 \mathrm{C}$ reform Institutional Possibility Frontier. For these agents, the Bolt case was an exogenous event that revealed that s. 18C in its current form had higher dictatorship costs than had previously been understood. Gelber and McNamara (2013: 479) characterise this effect by noting that the judgment 'generated anxiety among opponents of hate-speech legislation partly because it did not concern preconceived notions of the uncivil, explicitly racist material widely regarded as the subject of hate-speech laws'. For these opponents, their subjective understanding of costs diverged and separated from the previous institutional consensus. The red anti s. $18 \mathrm{C}$ reform Institutional Possibility Frontier depicts the views of the commentators who spoke against the repeal or amendment of s. 18C (Budarick 2014; Jakubowicz 2011; Langton 2014; Levey and Pringle 2013; Meyerowitz-Katz 2013; Migliorino 2013; Mundine 2013; 
Rice 2014; Soutphommasane 2014; Young 2013; Zerilli 2014). In their view, s. $18 \mathrm{C}$ had worked as intended, and that critics of s. $18 \mathrm{C}$ had failed to recognise the substantial disorder costs associated with hate speech.

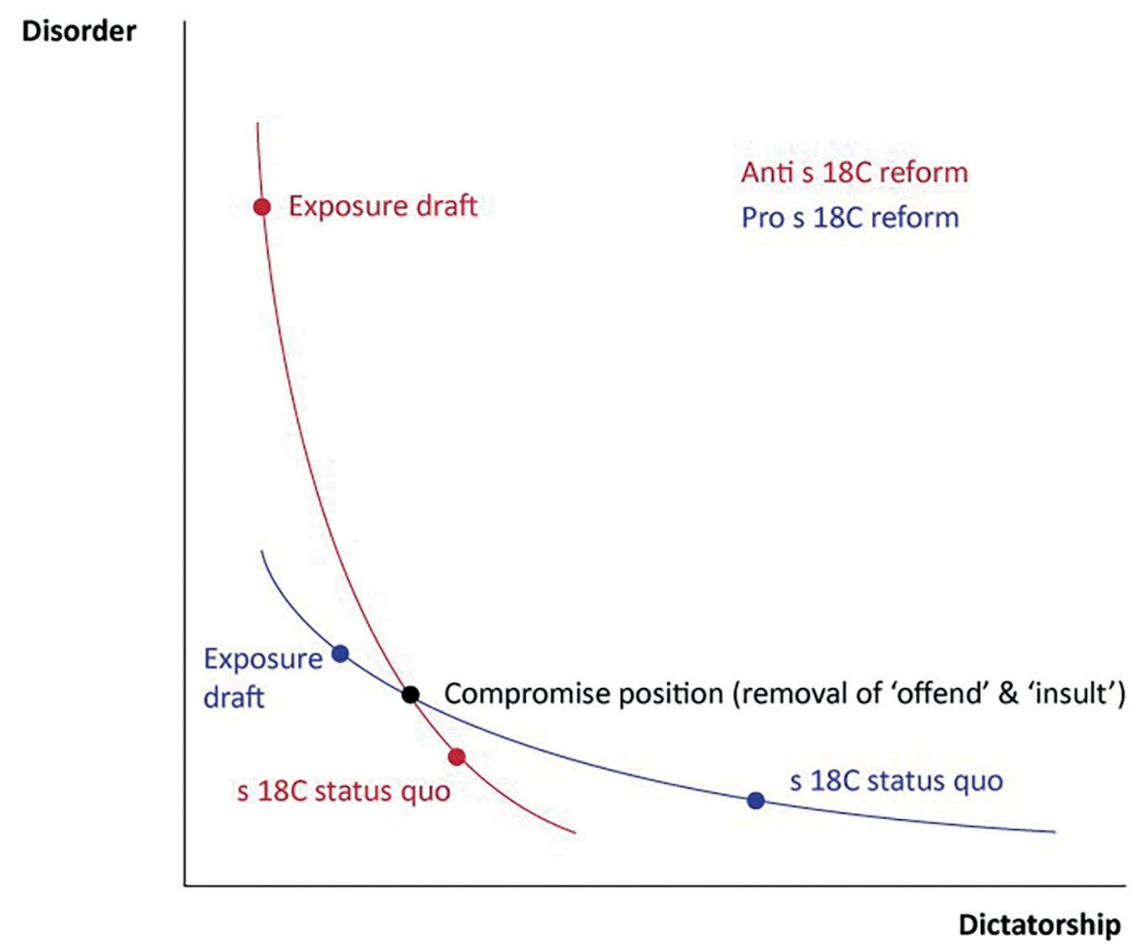

Figure 2: The Institutional Political Economy Frontier after the Bolt case

Diverging perceptions of relative costs presents an opportunity for compromise where the two Institutional Possibility Frontiers intersect with each other. While each agent will perceive the compromise as inefficient relative to their preferred institution, it will be more efficient than the alternative supported by their ideological opponents. In the case of s. 18C, a compromise position was proposed by some supporters of the intent of hate-speech legislation but who also believed the section had cast an excessively wide net. Marr (2011), for example, argued that 'freedom of speech was not at stake' in the Bolt case; rather, that Justice Bromberg had ruled against 'lousy journalism'. Nevertheless, he subsequently supported changes to the s. 18C, writing (Marr 2014) that:

the present act has to be changed - a little. Hurt feelings should never attract the law as they do now under section $18 \mathrm{C}$. Offence and insults are the everyday reality of free discourse. 
A number of other supporters of the provision of civil controls on hate speech spoke in favour of some amendment to s. 18C to lessen its burden on freedom of speech (Alcorn 2014; Australian Associated Press 2014; Gawenda 2014; Holmes 2011, 2014; Joseph 2014b; Karvelas 2014; Keane 2014; Munro 2011; Simons 2011). The Australian Press Council also expressed support for removing the word 'insult' from s. 18C (Johnston 2012). The most widely supported compromise position was removing the words 'offend' and 'insult' from s. 18C while leaving the rest of the provision intact.

In August 2012, then opposition leader Tony Abbott promised that he would 'repeal section 18C in its current form' (Abbott 2012). In March 2014 the Abbott Government released an exposure draft of the Freedom of Speech (Repeal of s. 18C) Bill 2014. This draft bill would have repealed the current s. 18C and 18D (as well as 18B and 18E), replacing them with provisions making it unlawful to 'vilify' or 'intimidate' a person or group of persons on the basis of race, colour or national or ethnic origin (subsection 1). Subsection (4) of the exposure draft vastly expanded the freedom-of-speech exemptions to include any communication in the course of participating in the public discussion of any political, social, cultural, religious, artistic, academic or scientific matter'. This last provision lacked any reference to good faith or reasonableness. The net effect of the exposure draft would have been very close to a full repeal of s. 18C (Berg 2014).

The public commentary in response to the exposure draft was substantially negative. One response to the draft by Aly (2014) was indicative. While arguing that s. $18 \mathrm{C}$ did not provide 'anything like substantial protection against racism', Aly condemned the exposure draft as 'the whitest piece of proposed legislation I've encountered during my lifetime'. Supporters of modest reform condemned the bill (Alcorn 2014; Dixon 2014; Holmes 2014; Joseph 2014a). For example, then Communications Minister, and subsequently Prime Minister, Malcolm Turnbull, was publicly sceptical about the exposure draft (Turnbull 2014) but supported the compromise position (Bourke 2015). Likewise, the president of the Australian Human Rights Commission (AHRC), Gillian Triggs, argued in defence of s. 18C (Triggs 2013a, 2014) but expressed support of some amendment of the provision (Packham 2013). The debate was not helped by an impolitic statement by the Attorney-General that 'people do have the right to be bigots' (Commonwealth Parliamentary Debates, Senate, 24 March 2014: 1,798), which Joseph (2014b) said implied the government 'supports racist speech' but was 'technically correct'. Members of the Abbott Government began to publicly state their opposition to the exposure draft. In August 2014 the Abbott Government announced that it was not proceeding with the exposure draft or any reform to s. $18 \mathrm{C}$. 
This turn of events is readily explained through the framework of subjective political economy. The exposure draft presented in March 2014 would have, from the perspective of the supporters of the status quo, led to more disorder costs than the status quo. Nor did it satisfy the supporters of moderate change and the compromise position, who saw it trading a small dictatorship cost for a much larger disorder cost. The Abbott Government's failure to bargain between these disparate perceptions of s. 18C's inefficiencies left it in a politically vulnerable position.

However, the increased subjective costs of legal restrictions on speech that offends and insults borne by the Bolt case were reflected in a parallel debate on the Gillard Government's Human Rights and Anti-Discrimination Bill (HRAD Bill) when it was released at the end of 2012. The HRAD Bill had its origins in the Rudd Government's National Human Rights Consultation, which reported in 2009. One of the consultation's recommendations was the consolidation of Australian human rights legislation, perhaps in a separate Human Rights Act (National Human Rights Consultation Committee 2009). While little proceeded from that the consultation, in 2011 the Gillard Government decided to 'consolidate existing Commonwealth anti-discrimination legislation into a single, comprehensive law' (Attorney-General's Department 2011). The HRAD Bill was the result of this process, and was released in draft form on 20 November 2012.

The HRAD Bill controversy was based on the fact that one provision echoed the language of s. 18C. Section 19(2) of the draft bill provided for a definition of discrimination that includes harassment. Section 19(2) applied to conduct in 'work and work-related areas' (s. 6). In s. 19(2)(b) discrimination was further defined as 'other conduct that offends, insults or intimidates' a person on the basis of the characteristics of 18 protected attributes. These protected attributes included race, religion, sex, sexual orientation, and age, but also industrial history, social origin, and political opinion (s. 17(1)). Conservative and libertarian critics focused on the words 'offend' and 'insult' in s. 19(2)(b) of the HRAD Bill, linking it with s. 18C and the Bolt case (Albrechtsen 2012; Bantik 2013; Berg 2012b; Bolt 2013a; Breheny 2012; Cater 2013; Fynes-Clinton 2013; Messmore 2012; Roskam 2012b; Sheehan 2013).

The initial response from the human rights community to the HRAD Bill was generally favourable (McKeon and Ball 2012). That changed, however, after former Chief Justice of the New South Wales Supreme Court James Spigelman spelled out the connection between s. 18C and the HRAD Bill, declaring that ' $[\mathrm{t}]$ he freedom to offend is an integral component of freedom of speech' and that, by prohibiting offensive and insulting conduct, both s. 18C and s. 19(2)(b) not only went too far but were opening Australia up to the charge that it was 'in breach of our international treaty obligations to protect freedom of speech' 
(Spigelman 2012). Spigelman's speech launched a host of criticism against s. 19(2)(b) from public supporters of the intent of the bill (Aroney and Parkinson 2013; Brown 2013; Irving 2013; Joseph 2013; Smith 2013; Walsh 2012). One month after Spigelman's address, Gillian Triggs (2013b) expressed support for amending the legislation to remove the words 'offend' and 'insult', 'if only to preserve the valuable reforms that the rest of the bill will provide'. At the end of January 2013 the Attorney General, Nicola Roxon, announced the government intended to redraft s. 19(2)(b). In March 2013 her successor in the portfolio, Mark Dreyfus, announced the government was not going to proceed with the HRAD Bill.

It is unlikely, in our assessment, that the debate over the HRAD Bill would have been so virulent had it not been introduced in the middle of a debate about s. 18C. The subjective increase in dictatorship costs of statutory language that prohibited offending and insulting someone according to protected attributes was confirmed by the HRAD Bill debate. The fact that these inefficiencies were identified by supporters of moderate change to 18C - Spigelman (2012) supported the purposes of hate-speech laws but criticised the use of the words 'offend' and 'insult' - underlined the subjective inefficiencies that the proposed bill would have represented.

\section{Ethics and accountability: The media regulation debate}

The second debate we look at is that which surrounded the Independent Inquiry into Media and Media Regulation, announced in September 2011, and the subsequent media reform bills of March 2013. The policy question in the media regulation debate was how to ensure that the print media - specifically Australia's small newspaper industry - upheld a high standard of journalistic ethics (Department of Broadband 2011).

Australia's print media in 2011 was controlled by a 'self-regulatory' system represented by the Australian Press Council (APC), a body established in 1976 that imposed binding standards of principles on its members. Violations were investigated at the instigation of a complaints system and the APC could impose corrective orders such as the publication of an apology. However, membership of the APC was voluntary, and the APC's power to impose corrective orders was counterbalanced by the fact that publishers could withdraw their membership. The West Australian Newspapers Group withdrew from the APC in 2012. Lidberg and Hirst (2013) and Finkelstein and Tiffen (2014) describe the origins of the 2011 media inquiry as the revealed weaknesses of this regulatory framework. In their view, the APC was constrained by its voluntary membership, 
had a low public profile, had insecure and inadequate funding, and its investigations were not made in a timely manner. Furthermore, the regulation of print media was distinct from the enforceable codes of conduct imposed on radio and television broadcasters by the Australian Communications and Media Authority, a statutory regulatory agency. As a result, 'the current Australian media regulation system put in place to regulate ethical transgressions by the press or broadcasters is complex, fragmented, and not user friendly' (Lidberg and Hirst 2013: 112).

Whatever the merits of the 2011 status quo, there was a sharp divergence in subjective Institutional Possibilities Frontiers following two events. The first was the 'phone hacking' scandal in the United Kingdom, in which a number of newspapers, including News Corporation's News of the World, were revealed to have hacked the private voicemails of celebrities and other newsworthy people in order to find stories. As the scandal was breaking in the UK in July 2011, Prime Minister Julia Gillard signalled the Australian Government's focus on News Corporation's Australian subsidiary, News Limited, by stating that the firm had 'questions to answer' (Thompson 2011). The second event was a political dispute between News Limited newspapers, the Gillard Government and the Greens, with whom the Gillard Government had made an agreement to form government after the 2010 election (Murphy 2011). Critics alleged that News Limited newspapers had a political agenda and published biased journalism in order to further that agenda (Lidberg and Hirst 2013). For example, Julia Gillard's speechwriter reflected that the media controls that came out of the media inquiry process were 'designed to break the irresponsible, politicised editorial culture' of News Limited and spoke of the 'News Corp problem' (Cooney 2015). From the perspective of these participants, the subjective disorder costs were irresponsible and partisan journalism targeted at the Gillard Government and the Greens. Their position is represented in Figure 3 by the red pro media control Institutional Possibilities Frontier.

In September 2011 the Gillard Government announced the formation of the Independent Inquiry into Media and Media Regulation: the Finkelstein Inquiry. Its mandate was two-fold: to inquire into the effectiveness of media codes of practice, regulation and the Australian Press Council; and to inquire into how technological change had affected media quality and regulation (Department of Broadband 2011). The inquiry's report was released in March 2012 (Finkelstein 2012). It recommended the establishment of a government News Media Council (NMC) that would 'set journalistic standards', and handle complaints made by the public, for radio, television, printed publications with a print run of 3,000 copies per issue, and 'news internet sites' with more than 15,000 'hits' per annum. Membership would be compulsory. The NMC would 
also take over the standards functions of the Australian Communications and Media Authority. The NMC would be able to order the publication of apologies and rights of reply. Compliance would be enforceable through court orders.

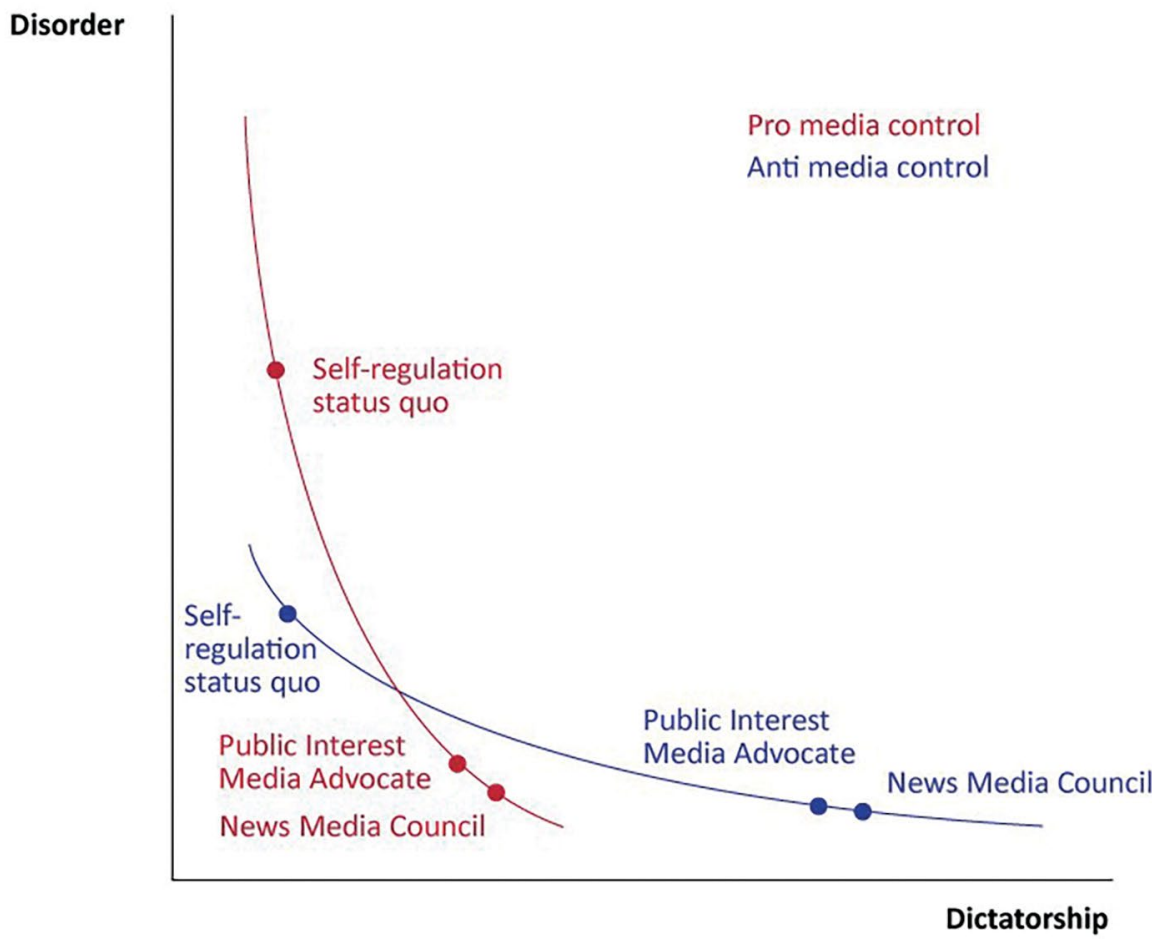

Figure 3: The Institutional Possibilities Frontier in the wake of the media regulation debate

In March 2013 the Gillard Government introduced to parliament a tranche of bills to act on the recommendations of the inquiry. The bills would have established a 'Public Interest Media Advocate' (PIMA). PIMA would be responsible for the approval of binding self-regulation schemes on both print and broadcast media. Participation in a regulatory scheme would be a requirement if media organisations wanted to take advantage of the privacy exemption relating to journalism by a media organisation under the Privacy Act 1988. PIMA was also to administer the public-interest test for mergers between significant media organisations. The proposal was described by the Gillard Government as a 'self-regulation' proposal. By leaving the option for media organisations not to participate, PIMA represented a step back on the Institutional Possibilities Frontier from the NMC proposed by the Finkelstein inquiry.

The debate over the recommendations of the inquiry and the bills of 2013 was fierce. The purportedly self-regulatory nature of the PIMA scheme was cited by the bills' defenders as a reason that freedom-of-speech concerns were 
overblown (Ackland 2013; Australian Human Rights Commission 2013; Hirst 2013; Tingle 2013). However, a 'self-regulatory' scheme that is binding, and on which statutory privilege rests, can hardly be seen as genuine self-regulation. PIMA is a good example of how unclear is the boundary between regulation and 'self'-regulation (see Berg 2008). Some noted the apparent rhetorical paradox of 'stronger self-regulation' through legislative change (Creagh 2013). However, most criticism rested on the more fundamental issue of press freedom and free speech - particularly the relationship between the Gillard Government's antipathy to News Limited, and the implication that the Finkelstein inquiry and the bills were revenge for hostile coverage (Akerman 2013; Albrechtsen 2013; Berg 2011; Bolt 2013b; Devine 2013; Henderson 2013; Roskam 2012a; Paterson $2011 \mathrm{~b}, 2013)$. Their position is depicted in Figure 3 as the blue anti media control Institutional Possibilities Frontier.

The strength of the reaction was taken by some supporters of increased social control as indicative of the need for that control in the first place (Carlton 2013; Forde 2013). For example, Lidberg and Hirst (2013) argue that the comparison made by The Daily Telegraph between the Communications Minister Stephen Conroy and 20th-century dictators who sought to suppress free media was itself one of the harms caused by the regulatory status quo. It is true that a comparison with international dictatorships was a recurring theme of the public debate. The package was compared with press restrictions in Burma (Jones 2013), Malaysia (Fernandez 2013), Vietnam (Tran 2013), in Australia during the Second World War (Henderson 2013), the Soviet Union (Devine 2013), and England before the end of press licensing (Paterson 2013). Translated into the terminology of the Institutional Possibility Frontier, Lidberg and Hirst (2013) are claiming that these commentators' professed fears of dictatorship costs were in fact evidence for the high disorder costs of the status quo. But costs are subjective to those who hold them. What Lidberg and Hirst describe is the sharply divergent subjective Institutional Possibility Frontiers of supporters and opponents of reform.

Indeed, a major accusation thrown about during the debate over media reform was that many participants were tainted by self-interest. Lidberg and Hirst (2013) argue that the antipathy of News Limited to the bills was motivated by self-interest. Likewise, opponents of the bills argued that they were motivated less by media standards and more to get even with the government's critics in the press. Media bias had been a major topic of political conversation during the Gillard Government. Labor's former Finance Minister, Lindsay Tanner, had written a book about the media and politics (Tanner 2011), and Labor supporters had been particularly frustrated with News Limited's perceived antipathy towards the Gillard Government (Cooney 2015). Allen and Berg (2016) argue that self-interest should also be seen through the prism of subjective costs. To the 
extent that individual political actors were engaged in the debate in pursuit of their material self-interests, those motives are empirically indistinguishable from 'public interest' motives. Both sides argued they were promoting democratic goals - reform proponents by reducing media bias and imbalance, reform critics by protecting free expression of ideas. Institutional preferences can be both self-interested and ideological.

In the event, the legislation did not pass the parliament. As Figure 3 shows, there was no obvious alternative institutional approach that would provide a compromise between the two starkly differentiated subjective Institutional Possibilities Frontiers during this debate. The Gillard Government found it did not have the numbers on the floor of the House of Representatives to pass the legislative package.

\section{Conclusion}

One of the recurring criticisms of the free-speech debate of 2011-13 is that it was narrowly focused on a small number of episodes while ignoring other, perhaps more serious, threats to freedom of speech. Commentators cited defamation law (Ackland 2015), restrictions on sending offensive material through the press (Stone 2015; Wilson 2011), the seizure of 'pornographic' art photographs (Altman 2014), restrictions on former prisoners speaking to the media (Ball 2013), and restrictions on the tax-deductible status of non-profit organisations engaged in advocacy (Orr 2014) as more concerning freedom-ofspeech issues. What distinguishes these threats from the s. $18 \mathrm{C}$ and media reform debates is the nature of the exogenous shock that modified the perceived tradeoffs between disorder costs and dictatorship costs. For example, if we assume that the current state of Australian defamation law reflects a compromise between competing visions of the need to protect freedom of speech (dictatorship costs) and the need to provide a defence against reputation damage (disorder costs), then no defamation case in the period studied sharply upset that compromise. We are not suggesting that Australia's defamation law is normatively desirable in its current form. Readers will have their own perceptions of the relative dictatorship and disorder costs of the current defamation regime and alternative institutions. But in the subjective political economy model, absent an exogenous shock, an evolution in ideas about those costs, or the invention of an institutional alternative that would satisfy more stakeholders, no political change is likely to occur. By contrast, the Bolt case represents one such shock. The fact that a prominent conservative commentator could be taken to court under s. $18 \mathrm{C}$ disrupted the status quo, giving new information about the subjective dictatorship costs of hate-speech laws to conservative, classical liberal, and libertarian commentators and politicians. Likewise, the phone-hacking scandal 
in the United Kingdom and the Gillard Government's hostile relationship with News Limited newspapers disrupted the status quo, leading to an increase in the subjective disorder costs of free speech in the media.

Institutional change, however, requires more than a disruption to the status quo. There must exist a viable alternative to the status quo. That alternative may only become viable as a result of the disruption - increased perceived dictatorship and disorder costs can be a spur to institutional innovation (Allen and Berg 2016). We suggest that such a position does exist in the instance of the Bolt case - to remove the words 'offend' and 'insult' from s. 18C. By contrast, there is (currently) no viable alternative to the status quo in the media regulation policy space. While in both cases the pre-2011 status quo remains, we suggest in the case of s. 18C that previous consensus is permanently disrupted and agents will continue to agitate for institutional change. At time of writing (September 2016) there is a substantial political debate within right-of-centre political parties in Australia for the repeal or amendment of s. 18C. By contrast we observe little agitation for media reform. This may suggest that the relevant shock was not the exposure of weaknesses in the regulation of the media but the Gillard Government's relationship with the press. That is, it was not the parliamentary defeat of the media law package that reduced the salience of the package, but Labor's loss at the 2013 federal election.

Further implications of the framework can be drawn from the fact that these debates occurred within a period of substantial technological change. Technological change affects the institutional status quo insofar as it changes the perceived trade-offs between disorder and dictatorship costs. The status quo in each issue analysed here was established before the rise of internet news media and social media platforms such as Twitter and Facebook. The question is how these technologies will affect the institutional trade offs. Social media and other internet media allows for the 'publication' of a larger volume of speech and a proportionate increase in the publication of speech that might be unlawful or violate normative ethical standards. This might be seen as increased disorder costs if current institutions are not adequately responding to undesirable speech. Online harassment and abuse is a major technological and social issue on platforms like Twitter. However, more publication opens up more opportunities for legal action under s. 18C. It is possible those opportunities will provide further information about the dictatorship costs of the status quo, strengthening pressure for reform. On the question of media control, a number of online-only publications have joined the APC, including HuffPost Australia, Private Media (which publishes Crikey), and At Large Media (which publishes New Matilda). However, the rapid growth of online journalism and quasi-journalistic outlets promises to put future pressure on the institutional status quo. 
The analysis we have presented here is positive rather than normative. For all that, the importance of freedom of speech as one of the pillars of a free society can be explored through a 'positive' institutional lens. Subjective political economy is a framework where dictatorship and disorder costs constitute information that needs to be discovered (Allen and Berg 2016). Exogenous events such as court cases and political crises are one such form of information. Changes in ideas, norms, and ideologies are another form of information. The spread of this information is itself subject to institutions of social control - that is, controls on expression. One of the possible dictatorship costs of limitations on free speech is that it would slow down agents' discovery of information about institutional costs and more desirable institutional alternatives. One value of freedom of speech is therefore that it facilitates institutional change that would reduce perceived institutional inefficiencies. This institutional approach contrasts with the 'marketplace of ideas' approach to freedom of speech associated with Mill (1859) or approaches founded in human liberty (Baker 1989; Berg 2012a).

An institutional analysis of the control of speech provides a deeper insight into the free-speech debate in 2011-13. Institutional change comes as the result of revealed subjective costs. What our approach cannot predict, however, is which events are likely to disrupt the status quo and whether viable alternatives to the status quo will present themselves.

\section{References}

Abbott, T. 2012, 'Freedom Wars', speech to the Institute of Public Affairs, Sydney, 6 August, resources.news.com.au/files/2012/08/06/1226444/197881120807-abbott-speech.pdf.

Ackland, R. 2013, 'Wild protests at a tiddlywinks approach', The Sydney Morning Herald, 14 March.

2015, 'Companies suing critics. That's the real enemy of free speech', The Guardian, 23 January.

Akerman, P. 2013, 'Labor sacrifices fair play in Orwellian bid to gag press', Hobart Mercury, 18 March.

_2014, 'When push comes to shovel', The Daily Telegraph, 6 June.

Albrechtsen, J. 2011, 'The real injury is to free speech', The Australian, 26 October.

2012, 'Nanny Roxon won't let you spit the dummy', The Australian, 27 December. 
_ 2013, 'And if this were Howard's bill?', The Australian, 20 March.

Alcorn, G. 2014, 'Racial vilification laws: checkmate for Andrew Bolt and George Brandis's ego', The Guardian, 7 August.

Allan, J. 2011, 'Andrew Bolt decision justifies repeal of a bad statute', The Australian, 30 September.

Allen, D. and Berg, C. 2016, 'Subjective Political Economy', SSRN working paper, ssrn.com/abstract $=2799032$.

Altman, D. 2014, 'Bolt, Brandis and the double standard on free speech', The Conversation, 21 March.

Aly, W. 2014, 'Brandis' race hate laws are whiter than white', The Age, 27 March.

Aroney, N. and Parkinson, P. 2013, Submission to Senate Legal and Constitutional Affairs Committee Exposure Draft of Human Rights and Anti-Discrimination Bill 2012.

Attorney-General's Department 2011, Consolidation of Commonwealth AntiDiscrimination Laws Discussion Paper.

Australian Associated Press 2014, 'Human rights lawyer says 18C went too far', SBS News, 29 March.

Australian Human Rights Commission 2013, Media Reform Bills Package, Draft Submission to the Senate Standing Committees on Environment and Communications.

Australian Law Reform Commission 2014, Serious Invasions of Privacy in the Digital Era, Australian Law Reform Commission, Sydney.

Baker, C.E. 1989, Human Liberty and Freedom of Speech, Oxford University Press, New York and Oxford.

Ball, R. 2013, 'Who's less free: Andrew Bolt, or children in detention?', The Guardian, 19 December.

Bantik, C. 2013, 'Censorship dressed up is denial of free speech', The Australian, 30 January.

Baume, M. 2011, 'Relic should be repealed', The Australian Financial Review, 11 October.

Berg, C. 2008, The Growth of Australia's Regulatory State: Ideology, Accountability and the Mega-Regulators, Institute of Public Affairs, Melbourne, Australia. 
-2010, 'Silenced in Court', The Sunday Age, 3 October.

— 2011, Submission to the Independent Media Inquiry, Institute of Public Affairs.

_ 2012a, In Defence of Freedom of Speech: from Ancient Greece to Andrew Bolt, Institute of Public Affairs, Melbourne.

-2012b, 'Memo to government: having an opinion is not a crime', The Sunday Age, 23 December.

- 2014, 'Politics Stands In The Way Of A Full 18C Repeal', The Drum, 25 March.

Bolt, A. 2009a, 'It's so hip to be black', The Herald Sun, 15 April.

_ 2009b, 'White fellas in the black', The Herald Sun, 21 August.

_ 2013a, 'PM's human rights Bill a bum deal', The Herald Sun, 31 January.

-2013b, 'We have diversity (just not the kind Labor wants)', The Herald Sun, 14 March.

Bourke, L. 2015, 'Malcolm Turnbull endorses changes to Racial Discrimination Act', The Sydney Morning Herald, 17 May.

Breheny, S. 2012, 'Proposed Law A Further Attack On Free Speech', The Australian, 23 November.

- 2014, 'Coalition about-face on hatred disappoints', The Australian, 28 February.

Brown, A. 2013, 'Big picture lost in debate over anti-discrimination laws', The Drum, 30 January.

Brown, N. 2014, 'Putting balance back into the racial discrimination debate', Online Opinion, 17 March.

Buchanan, J. 1975, The Limits of Liberty: Between Anarchy and Leviathan, Liberty Fund: Indianapolis.

Budarick, J. 2014, 'Debate on free speech alone means little for minorities', The Conversation, 20 August.

Bueno de Mesquita, B., Smith, A., Siverson, R.M. and Morrow, J.D. 2003, The Logic of Political Survival, MIT Press, Cambridge.

Burgess, C. 2013, 'Criminal defamation in Australia: Time to go or stay', Murdoch University Law Review 20: 1. 
Carlton, M. 2013, 'Once again tyranny rears its ugly head', The Sydney Morning Herald, 16 March.

Cater, N. 2013, 'No joke to offend coalition of censorious in these Roxonated times', The Australian, 12 March.

_ 2014, 'Abbott must fix problems in Race Act', The Australian, 18 March.

Cooney, M. 2015, The Gillard Project, Penguin Australia, Australia.

Costello, P. 1994, 'Debate, Not Laws, Should Fight Racism', The Age, 1 November.

Creagh, S. 2013, 'Conroy proposes media reforms: the experts respond', The Conversation, 12 March.

Davidson, S. 2011, 'Bolt is Guilty But the Law is Wrong ... Let The Markets Deal With Racial Discrimination', The Conversation, 29 September.

Debelle, P. 2001, 'Free speech row on Holocaust website', The Age, 10 April.

Department of Broadband 2011, Independent Media Inquiry, web.archive. org/web/20130421040913/http://www.dbcde.gov.au/digital_economy/ independent_media_inquiry.

Devine, M. 2013, 'Sneers for Piers and a free press', The Daily Telegraph, 20 March.

Dixon, J. 2014, Liberty Victoria Submission: Exposure draft-Proposed Changes to the Racial Discrimination Act, Liberty Victoria.

Djankov, S., Glaeser, E.L., La Porta, R., Lopez-de-Silanes, F. and Shleifer, A. 2003, 'The New Comparative Economics', Journal of Comparative Economics 31(4): 595-619.

Fernandez, J.M. 2013, 'Insidious Draconian Treacherous', The Sunday Times, 17 March.

Finkelstein, R. 2012, Report of the Indepedent Inquiry into the Media and Media Regulation, Australian Government.

Finkelstein, R. and Tiffen, R. 2014, 'When Does Press Self-Regulation Work?', Melbourne University Law Review 38: 944.

Forde, S. 2013, 'Media reform: hysterical attacks on weak Conroy suggestions tell the real story', The Conversation, 13 March.

'Free speech has to include freedom to offend' 2012, The Age, 8 August.

'Freedom of speech needs liberating' 2013, The Saturday Age, 21 December. 
Fynes-Clinton, J. 2013, 'There's no pride in ruling on prejudice', The CourierMail, 24 January.

Gawenda, M. 2014, 'Hate is not a dirty word', Business Spectator, 5 March.

Gelber, K. and McNamara, L. 2013, 'Freedom of speech and racial vilification in Australia: "The Bolt case" in public discourse', Australian Journal of Political Science 48(4).

Henderson, G. 2013, "National interest" is in Labor's interest', The Sydney Morning Herald, 19 March.

Hirst, M. 2013, 'Explainer: Conroy's proposed new media laws', The Conversation, 19 March.

Hirst, M. and Keeble, K. 2012, 'I am not a racist: Andrew Bolt and free speech', antiThesis 22: 1-16.

Holmes, J. 2011, 'Bolt, Bromberg and a profoundly disturbing judgment', The Drum, 30 September.

-2014, 'Racial Discrimination Act amendments are either stupid or shameful', The Age, 22 April.

Irving, H. 2013, 'Anti-discrimination bill is (probably) constitutional, but should be reined in regardless', The Conversation, 24 January.

Jakubowicz, A. 2011, 'Andrew Bolt, racism and the internet', The Conversation, 29 September.

Johns, G. 2014, 'Race-hate war is already won', The Australian, 12 March.

Johnston, M. 2012, 'Press Council backs changes', The Herald Sun, 1 March.

Jones, G. 2013, 'PM finds common ground with Burma government', The CourierMail, 19 March.

Joseph, S. 2013, 'The Media is Offended by the new Discrimination Bill', The Conversation, 10 January.

- 2014a, 'Rights to bigotry and green lights to hate', The Conversation, 28 March.

-2014b, Submission on the repeal of section 18C of the Racial Discrimination Act, Castan Centre for Human Rights Law.

Karvelas, P. 2014, 'Jewish leader eyes middle path on race act reform', The Australian, 15 April. 
Keane, B. 2014, 'On race, discrimination and white men's privilege', Crikey, 21 March.

Kemp, D. 2011, 'Vile law should be abolished', The Australian, 5 October.

Kenny, C. 2014, 'A free and vigorous debate would be the best avenue for Bolt's detractors', The Australian, 29 March.

Langton, M. 2014, 'Our race act has had a civilising effect: leave it be', The Australian, 8 May.

Levey, G.B. and Pringle, H. 2013, 'Why the "Bolt laws" should stay', The Drum, 28 November.

Lidberg, J. and Hirst, M. 2013, 'In the Shadow of Phone Hacking: Media Accountability Inquiries in Australia', The Political Economy of Communication 1(1): $111-21$.

Lynch, A., McGarrity, N. and Williams, G. 2015, Inside Australia's AntiTerrorism Laws and Trials, NewSouth Publishing, Sydney.

Manne, R. 1994, 'Race Bill an Offence Against Free Speech', The Age, 16 November.

Marr, D. 2011, 'In black and white, Andrew Bolt trifled with the facts', The Sydney Morning Herald, 29 September.

_ 2014, 'David Marr on race, votes and free speech', The Saturday Paper, 5 April.

McCloskey, D.N. 2015, 'Max U versus Humanomics: a critique of neoinstitutionalism', Journal of Institutional Economics: 1-27.

McGuinness, P.P. 1994, 'Racial Hatred Bill Is A Legislative Lie', The Age, 12 November.

McKeon, S. and Ball, R. 2012, 'Proposed anti-discrimination reforms will strengthen equality', The Drum, 22 November.

Meagher, D. 2004, 'So Far So Good: A Critical Evaluation of Racial Vilification Laws in Australia', Federal Law Review 32: 225.

Merkel, R. 1994, 'Does Australia Need a Racial Vilification Law?', Quadrant 38(11): 19 .

Merritt, C. 2014, 'Race act's 18C brings law into disrepute', The Australian, 7 March. 
Messmore, R. 2012, 'With law on their side, everyone's a victim', The Australian, 28 December.

Meyerowitz-Katz, D. 2013, 'Anti-Abuse laws pose no real threat to freedom of speech', The Australian, 9 December.

Migliorino, P. 2013, 'Attorney-General George Brandis' review of racial vilification laws a blow for protection', The Age, 25 November.

Mill, J.S. 1859, On Liberty, J.W. Parker and Son, London.

Mundine, W. 2013, 'Racial vilification legislation is not about freedom but about how we think about race', The Age, 18 December.

Munro, P. 2011, 'Judge's discrimination ruling creates unusual bedfellows', The Age, 2 October.

Murphy, K. 2011, 'Greens press government to support media inquiry', The Sydney Morning Herald, 10 September.

National Human Rights Consultation Committee 2009, Report, AttorneyGeneral's Department, Canberra.

Norton, A. 1994, 'Speech censors can hurt a precious right', The Sydney Morning Herald, 18 July.

O'Neill, B. 2014, 'Abolish the Human Rights Commission, and return us to the Enlightenment's positive values', The Australian, 3 May.

Olson, M. 1965, The logic of collective action: public goods and the theory of groups, Harvard University Press, Cambridge.

Orr, G. 2014, 'The Freedom to be a Hypocrite', Inside Story, 11 August.

Packham, B. 2013, 'Tim Wilson facing clash with Human Rights Commission colleagues over "Andrew Bolt" race provisions', The Australian, 18 December.

Paterson, J. 201la, 'Bolt case highlights discriminatory act', The Drum, 29 September.

- 2011b, 'Media Inquiry Opens The Door To Intimidation', The Australian Financial Review, 16 September.

— 2013, 'Conroy's media regulation proposals fail the public interest test', The Australian, 13 March.

Pearson, M. 2012, 'The media regulation debate in a democracy lacking a free expression guarantee', Pacific Journalism Review 18(2): 89. 
Rice, S. 2014, Why free speech comes at a price: Reflections on race, civility and the law, Inaugural Research Seminar, Deakin University School of Law in association with Sladen Lega.

Rodrik, D. 2014, 'When Ideas Trump Interests: Preferences, World Views, and Policy Innovations', The Journal of Economic Perspectives 28(1): 189-208.

Roskam, J. 2012a, 'A Failure To Defend Liberty', The Australian Financial Review, 9 March.

_ 2012b, 'Boiling frog of personal freedom', The Australian Financial Review, 7 December.

— 2014, 'When free speech went cheaply', The Australian Financial Review, 15 August.

Rosser Jr, J.B. and Rosser, M.V. 2008, 'A critique of the new comparative economics', The Review of Austrian Economics 21(1): 81-97.

Rubenstein, C. 1994, 'Anti-racist Laws Will Not Restrict Responsible Debate On Society', The Age, 21 September.

— 2014, 'Upsetting the balance', Australia/Israel Review, May.

Ruehl, P. 1997, 'Free speech takes a bath in the pool of rights', Daily Telegraph, 14 August: 11.

Sammut, J. 2014, 'We'll still be a melting pot', The Spectator, 15 March.

Sheehan, P. 2013, 'Racial hatred bill offers open slather to obnoxious', The Sydney Morning Herald, 14 January.

Shleifer, A. 2005, 'Understanding Regulation', European Financial Management 11(4): 439-51.

Simons, M. 2011, 'Bolt decision: "Irresponsible journalism illegal"? Think again', Crikey, 29 September.

Smith, B. 2013, 'Free speech and other human rights: the clause that almost sank the Human Rights Bill', The Conversation, 1 February.

'Smothering Free Exchange of Ideas a Dangerous Path', The Australian, 29 March 2014.

Soutphommasane, T. 2014, 'Racism is a Moral Issue', ABC Religion and Ethics, 22 April. 
Spigelman, J. 2012, 'Human Rights Day Oration', Australian Human Rights Commission.

Stone, A. 2015, 'The Ironic Aftermath of Eatock v Bolt', Melbourne University Law Review 38(3).

Tanner, L. 2011, Sideshow: dumbing down democracy, Scribe, Carlton North, Vic.

Tate, J.W. 2016, 'Free speech, toleration and equal respect: the Bolt affair in context', Australian Journal of Political Science 51(1): 34-50.

Thompson, J. 2011, 'News Ltd has questions to answer, PM says', ABC News, 20 July.

Tingle, L. 2013, 'The pillars of society are crumbling around us', The Australian Financial Review, 15 March.

Tran, V. 2013, 'Living under a regime of government censorship', Daily Telegraph, 19 March.

Triggs, G. 2013a, 'Freedom of speech is not in danger in Australia', The Australian, 25 February.

_ 2013b, 'Tweaking the draft bill could preserve core reforms', The Australian, 22 January.

- 2014, 'Proposed changes to the Race Discrimination Act: Bad cases make bad law', The Australian, 28 March.

Turnbull, M. 2014, What do you think about changes to the Racial Discrimination Act - exposure draft seeks consultation, www.malcolmturnbull.com.au/ media/what-do-you-think-about-changes-to-the-racial-discrimination-actexposure-d.

van Gend, D. 2014, 'Above all liberties', Online Opinion, 17 March.

Walsh, K. 2012, 'Laws may add injury to insult', The Australian Financial Review, 12 December.

Walsh, P. 1995, 'The burden of babbling bills', The Australian Financial Review, 25 July, p. 15.

— 2013, 'Anti-terrorism laws a test of Attorney-General George Brandis' commitment to freedom of speech', The Sydney Morning Herald, 31 December.

Willox, I. 1995, 'Howard Signals Fight Over Race Bill', The Age, 7 March, p. 3. 
Wilson, J. 2011, 'When freedom of speech meets conservative double standards', The Drum, 6 October.

Wilson, T. 2014, 'The Forgotten Freedoms', Sydney, 13 May, www.humanrights. gov.au/news/speeches/forgotten-freedoms.

Windschuttle, K. 2014, 'Why Section 18C Can't Silence Racists', Quadrant 58(6).

Young, N. 2013, 'Tim Wilson defends free speech, but will that include racist abuse?', The Guardian, 18 December.

'Your right to speak freely', 2014, The Herald Sun, 12 March.

Zerilli, J. 2014, 'Free speech: what it is and what it isn' $\mathrm{t}^{\prime}$, The Conversation, 26 February. 
This text is taken from Agenda, Volume 23 - Number 1, 2016, edited by William Coleman, published 2016 by ANU Press, The Australian National University, Canberra, Australia. 